\title{
A Review on GIS-based Approach for Road Traffic Noise Mapping
}

\author{
Dipeshkumar R. Sonaviya* and Bhaven N. Tandel \\ Department of Civil Engineering, SVNIT, Surat - 395007, Gujarat, India; dipeshsonaviya2589@gmail.com, \\ bnt@ced.svnit.ac.in
}

\begin{abstract}
Objectives: Road traffic noise pollution is identified as one of the serious alarms that influence the attribute of the urban regions. This study highlights the different models used for noise mapping using GIS. Methods: Interpolation (krigging) method can be used to develop different noise contour maps. Noise emission levels are calculated from many sound propagation models like ISO 9613:1996, Calculation of Road Traffic Noise (CoRTN 88), Harmonoise Noise Prediction Algorithm and Nord 2000. Findings: In study of road traffic noise mapping, noise levels have been predicted using a specially developed noise computer models. The output results of the computer noise models can add as input data for a GIS. The interpolation methods available in GIS can develop noise contour maps. Application: This study highlights the different Geographic Information System techniques applied for the noise mapping.
\end{abstract}

Keywords: Environmental Pollution, Geographical Information System, Noise Mapping, Propagation Models, Road Traffic Noise

\section{Introduction}

Water pollution, air pollution, and noise pollution have always been universal anxiety, which affects the public's health and the earth's brittle ecosystems. Among all the pollution, one of the grave and major issues of the environment is noise pollution. It is a growing problem of communities in large urban areas. Studies on noise pollution show that more than twenty percent of the globe population exist under deniable noise levels and about $60 \%$ of the European population is exposed to serious noise levels during a daytime ${ }^{1}$. Health-related issues like physiological disorders, psychological disorders, hypertension, and ischemic heart diseases are seen nowadays 2 . There are various harmful sources of ambient noise on public places like industrial activity, construction activity, huge machine sets, loudspeakers, music systems, vehicular horns, and other mechanical devices, which affect the human being health, and the psychology of human.

A skill of measuring traffic noise level and signify them on geographical information system map can pro- vide a powerful set of tools for recognized noise sources, its rising influence, management and take judgments relating to its control measurements ${ }^{3}$. The major source of environmental pollution is a road traffic noise in urban areas. Several nations have proposed limits for vehicular noise and allotted guidelines to control road traffic noise ${ }^{4}$ . For a developing nation like India, where the growth of urbanization is quite high, vehicular noise is a significant source of environmental noise pollution ${ }^{5}$. In the face of sudden traffic route, traffic is increased and it results in increase noise level ${ }^{6}$.

The geographical information system can give a strong set of tools for collecting, recovering, converting and picturing spatial data from the real world for suitable purposes. In GIS, cataloging and meta-data organization systems are used to trace data handling at every step of the process. These systems contain variations in input data, interpretation of the data, interpolation techniques, calculation methods and its settings, which can affect the precision of the output results. Therefore, the geographical information system is an important tool which aids in the study of noise pollution.

*Author for correspondence 
The geographical information system can provide the graphical visualization of the impact of noise and an additional tool that is used for analyzing the outcomes ${ }^{7}$. Noise mapping can be done using appropriate GIS software for better graphic representation of the noise impact and its daily variations. Interpolation (krigging) technique can be used to develop contour maps that show the noise level variations and so it is an effective technique for the intention of noise mapping. In the interpolation technique, kriggingcan be done to evaluate the acoustic behavior of the topographical region. This review paper discusses on the integration of GIS with noise prediction models and GIS-based approach for noise mapping can provide a precise and fast assessment of the noise impact in the environment ${ }^{-}$. GIS can give better graphical acquaintance of the areas with maximum noise levels, traffic accumulations and classifies the most exposed areas under the noise pollution peril.

\section{Noise Propagation Models}

Environmental noise modeling can define as a procedure of ideally estimating noise levels within an area of attention under a particular set of circumstances. Noise model can define the noise sources, important features of the environment through which sound can propagate to the receiver, and its calculation methods. There are various standards used for noise modeling. Few commonly used sound propagation models are ISO 9613: 1996, calculation of road traffic noise (CoRTN88), harmonoise noise prediction algorithm, Nord 2000.

\subsection{ISO 9613: 1996}

"ISO 9613 can represent the sound attenuation calculating method during propagation outdoors at a distance from various sources for predicting noise level. The prediction of the equivalent continuous A-weighted sound pressure level can be predicted by this model. The procedure of accounting A-weighting for the comparative loudness can be observed from instrument readout value. The instrument can also account for low audio frequencieswhich unperceivable to human's ears ${ }^{2}$. ISO 9613 is appropriate for the various types of noise like a road traffic noise, industrial noise, construction activities noise, rail noise and many various types of noise sprig. ISO 9613 model is the base of many others sound propagation models like Harmonoise prediction model, Nord2000 model, and CoRTN88 model.

\subsection{Calculation of Road Traffic Noise Model (CoRTN88)}

The CoRTN88 includes noise indices as if $\mathrm{L}_{10}$ (18 hours) and $\mathrm{L}_{10}$ ( 1 hour). These indices have the sound level values which are exceeded $10 \%$ of the time in 18 hours period and 1-hour period. The CoRTN88 also considers the average speed of vehicular traffic, heavy traffic percentage, low traffic flow, road width, slope, barriers, ground exploitation and its angle of view, retained cut and opposite facade.

\subsection{Harmonoise Noise Prediction Algorithm Model}

The attenuation can be calculated with the help of harmonoise prediction algorithm by gathering the combined effects of ground, air exploitation, shielding by topography, atmospheric refraction, and scattering. This model can calculate attenuation which cannot be calculated by the ISO $9613^{10}$.

\subsection{Nord 2000}

Danish Environmental Protection Agency introduced the nordic noise prediction standard for strategic mapping of road and railway noise. Nord2000 has source model for road and rail traffic in the third-octave bands from 2 $\mathrm{Hz}$ to $10 \mathrm{kHz}$. It can be used for different weather classes. There are nine weather classes available for the calculation in these altered weather classes. Nord 2000 model can consider eight different types of ground surface ranging from very soft to very hard, at that, only soft and hard can be used for noise modeling ${ }^{11}$.

\section{GIS Noise Mapping}

GIS software can create noise maps for better visual information of the noise and its variations in the environment ${ }^{5}$. The Interpolation (krigging) is the most important technique for the purposes of noise mapping and its technique can be used to develop noise levels contours ${ }^{12}$. Kriggingcan be done considering the acoustic behavior of the topographical region in interpolation technique. The noise contour maps can be created to show the variation of the environment noise at different times of the day in the urban area. GIS can be used for the better result for the outcome of the area with high noise intensity and traffic properties. It also recognizes the most exposed 
zones under the noise pollution bluster. Noise maps can be achieved for the adopting clear methodology. Such a methodology can involve the following steps:

\subsection{Global Posting System Data Collection}

Various methods use for the collecting high-accuracy GPS data and it depends on several factors like the objective of the survey preferred precision, equipment availability and field logistics. Supreme accuracy normally requires a more adamant field practice. The most common GPS survey methods are Continuous survey method, Static survey method, Rapid Static survey method, and Kinematic survey methods. The noise data collected from the field can insert into the GIS and display on the cadastral map of the urban area. The distance between points in the mapvaries from the highly habitable region to less habitable areas. Each point contains attribute data like topographical coordinates, location, date and time of data collection, a major source of noise, noise indices, maximum logged noise level, minimum logged noise level,andan average noise level.

\subsection{Spatial Database Development}

Database defined as a collection of information in the form of table form. The outcomes in form of tables depending on the sensitivity of data collected in the survey. The spatial database is built up from four types of spacious collected data which are GPS noise location, noise level readings, noise sources, and noise impacts. GPS noise location can be used for locating the geographical points where noise levels reading can record. It also includes a particular location ID which is used for a geographic pointer to tie the database altogether. Noise level readings are described in the form of decibel $(\mathrm{dB})$. Noise sources can be defined as survey information about the major source of noise and its impacts can deal with noise study on human health and their behavior.

\subsection{Spatial Modeling}

The spatial modeling can be defined as a particular form of dis-aggregation of an area which is divided into a number of grids like squares or polygons. The model may be linked to a GIS for the data input and display. There are basically two types of spatial modeling techniques, vector, and raster which are available with an application in GIS tools. The spatial models are used to recognize the spatial cleavage of noise pollution.

\subsection{Surface Interpolation Technique by using IDW}

The interpolation is a technique to envisage the cell value at a position that deficit the point. It can work on the principle of the special auto reformation or spatial dependency, that measure the relationship between nearby and distant object item. The interpolation technique of the ground surface can define all specimens to calculate every output in form of the grid cell values and this cell value can be found out by inverse distance weighted (IDW) interpolation method using a linearly weighted grouping of the sample points. The function of inverse distance is a weighted. The inverse distance weighted can control the impact of known points, the interpolate values and their distance from the output point. IDW can provide precise weighted interpolate surface grid value and structure.

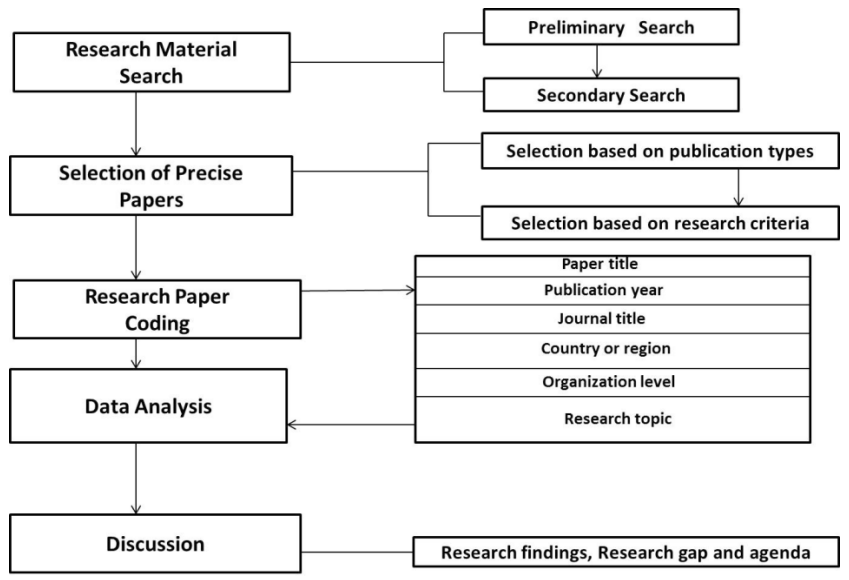

Figure 1. The process of a systematic review of studies.

\section{Review of GIS-based Traffic Noise Mapping}

The main process of a systematic review can be carried out for GIS-based noise mapping study that is illustrated in Figure 1. The first three steps target to gather sufficient applicable publications linked to GIS and noise mapping study. Through primary search, the maximum numbers of the papers from the journals of the traffic noise mapping can be recognized as pursuit journals for the subsidiary or secondary search. The secondary search is used to pick the literature, pursuant to types of publication and its criteria. The elected papers can be amassed and encoded from nine facets. On the substratum of encod- 
Table 1. An extensive review of the literature on noise mapping

\begin{tabular}{|c|c|c|c|}
\hline SI.No & Year & Country & Major Findin \\
\hline 1. & 2004 & UK & The geospatial handling technique was described to capture, contrive, and process survey data ${ }^{16}$. \\
\hline 2. & 2005 & Croatia & $\begin{array}{l}\text { The Applications were described for the noise mapping method as an efficient tool in the } \\
\text { environmental protection master plan of the Holcim cement plant } t^{17} \text {. }\end{array}$ \\
\hline 3. & 2006 & Ireland & Noise map was prepared using GIS which integrated with harmonoise prediction model ${ }^{18}$. \\
\hline 4. & 2006 & Turkey & Prepared noise contour map using interpolation method available in GIS for Sanliurfacity ${ }^{12}$. \\
\hline 5. & 2006 & Turkey & $\begin{array}{l}\text { GIS-based noise mapping had been done of Konya city. There were } 366 \text { sampling point selected } \\
\text { on main roads in the city Centre }{ }^{6} \text {. }\end{array}$ \\
\hline 6. & 2007 & Netherland & $\begin{array}{l}\text { 3-D noise model developed in GIS to analyze the three-dimensional effect of noise pollution in } \\
\text { Delft city }{ }^{19} \text {. }\end{array}$ \\
\hline 7. & 2007 & Lebanon & $\begin{array}{l}350 \text { sampling point was selected for noise monitoring over the } 3.5 \mathrm{~km}^{2} \text { of the town and } \\
\text { prepared on noise map for the city. The limits of noise levels reading were seen to be much } \\
\text { higher than admissible standards }{ }^{20} \text {. }\end{array}$ \\
\hline 8. & 2007 & US & $\begin{array}{l}\text { The noise maps were created of traffic and rail noise over the county using GIS and CAD data in } \\
\text { the sound propagation model }{ }^{21} \text {. }\end{array}$ \\
\hline 9. & 2008 & Spain & $\begin{array}{l}\text { The noise map was created from urban prediction model of Pamplona, Spain using two } \\
\text { computerprograms }{ }^{22} \text {. }\end{array}$ \\
\hline 10. & 2009 & Iran & $\begin{array}{l}\text { The model was developed for } 282 \text { sampling points of the road traffic noise in the city of } \\
\text { Hamadam based on trafficbehavior. Statistical regression model developed for road condition }{ }^{23} \text {. }\end{array}$ \\
\hline 11. & 2009 & India & $\begin{array}{l}\text { Leq for day time ranged between } 51.2 \text { and } 89.0 \mathrm{~dB}(\mathrm{~A}) \text { and for night time, it ranged between } \\
43.5 \text { and } 81.9 \mathrm{~dB}(\mathrm{~A}) \text {. The computed data were mapped by GIS for Asansol city }{ }^{24} \text {. }\end{array}$ \\
\hline 12. & 2010 & Iran & $\begin{array}{l}\text { The study of the noise indices like } \mathrm{L}_{\text {min }}, \mathrm{L}_{90} \text {, and } \mathrm{L}_{50} \text { showed that the background noise in the } \\
\text { region was higher than the standards and the developed model was integrated within GIS } \\
\text { software }{ }^{25} \text {. }\end{array}$ \\
\hline 13. & 2011 & India & $\begin{array}{l}\text { Noise pollution study carried out on three of the busiest urban corridors of Surat city and the } \\
\text { regression model was built }{ }^{26} \text {. }\end{array}$ \\
\hline 14. & 2011 & India & $\begin{array}{l}\text { Noise assessment was carried out at various locations of Guwahati city. Highest noise levels } \\
\text { had been found between } 80 \text { to } 90 \mathrm{~dB}(\mathrm{~A}) \text { found at commercial area, 65-75 dB (A) at residential } \\
\text { areas, } 65-75 \mathrm{~dB}(\mathrm{~A}) \text { at silence zone }{ }^{5} \text {. }\end{array}$ \\
\hline 15. & 2012 & India & $\begin{array}{l}\text { The maximum Leq } 72.25 \mathrm{~dB}(\mathrm{~A}) \text { was recorded at industrial cum residential zone, } 64.47 \mathrm{~dB} \\
\text { (A) at commercial cum residential zone, } 63.71 \mathrm{~dB}(\mathrm{~A}) \text { at educational zone, } 53.26 \mathrm{~dB}(\mathrm{~A}) \text { at } \\
\text { entertaining zone and } 42.84 \mathrm{~dB}(\mathrm{~A}) \text { at silence } \text { zone }^{27} \text {. }\end{array}$ \\
\hline 16. & 2012 & India & $\begin{array}{l}\text { The equivalent noise levels measured at various locations had been ranging from } 53 \mathrm{~dB}(\mathrm{~A}) \text { to } \\
83 \mathrm{~dB}(\mathrm{~A}) \text {. Noise map was prepared using GIS }{ }^{28} \text {. }\end{array}$ \\
\hline 17. & 2012 & Turkey & 50 points ware selected for noise monitoring and prepared noise maps using GIS ${ }^{29}$. \\
\hline 18. & 2013 & China & $\begin{array}{l}\text { The noise map was created for the urban areas using noise mapping tool available in GIS in } \\
\text { form of grid arrangement }{ }^{30} \text {. }\end{array}$ \\
\hline 19. & 2013 & India & $\begin{array}{l}\text { The empirical noise prediction model was created. The value of Leq ranged from } 60 \text { to } 87 \mathrm{~dB} \\
\text { (A). Traffic Noise Index (TNI) exceed by } 70 \mathrm{dBA} \text { in Chennai City }{ }^{31} \text {. }\end{array}$ \\
\hline 20. & 2013 & Jordan & $\begin{array}{l}\text { This study was carried out to develop the contour maps which indicate the noise impact and its } \\
\text { variations in Amman city }{ }^{32} \text {. }\end{array}$ \\
\hline 21. & 2013 & India & $\begin{array}{l}\text { Noise level was exorbitant with more than } 85 \mathrm{~dB}(\mathrm{~A}) \text { average across the city during the peak } \\
\text { hour traffic. Many schools, hospitals were situated in the heart of the Tripura city was affected } \\
\text { by the noise pollution }{ }^{33} \text {. }\end{array}$ \\
\hline 22. & 2014 & China & $\begin{array}{l}\text { Road traffic noise map was prepared using GIS and GPS for Guangzhou city. The average error } \\
\text { between the estimated and measured values was below } 2.0 \mathrm{~dB}(\mathrm{~A})^{34} \text {. }\end{array}$ \\
\hline 23. & 2015 & India & $\begin{array}{l}\text { The noise variation map was prepared by considering the joint effect of mobile and stationary } \\
\text { sources of noise in Chandigarh }{ }^{35} \text {. }\end{array}$ \\
\hline
\end{tabular}


ing sequel of nine facets, investigation of the data can be carried through to have the oversight of studies. The research areas can be debated from sequential and topical perspectives, with a view to tender suitable findings of the research. The research gaps can be finally recognized to cicerone proposed research on noise mapping $\frac{13-15}{}$.

The objective of the study is not to mileage a total list of papers, but rather to discover the recent tendencies, beneficial research area and gaps in GIS-based approach for the noise mapping. The certain types of papers are not paired with the research topic but pair with the research plan. A primary review study should be lead via analysis result, summaries, conclusion, and keywords of the papers. Here, Table 1 shows the major finding in noise pollution research.

\section{Critical Summary and Conclusion}

This study reviews the existing literature on GIS and noise mapping gives essential clarification in terms of definitions, concepts of GIS, sound propagation models. Noise pollution can affect human life. Traffic is the chief source of noise pollution in growing urban areas.

Noise pollution is not only causing environmental but it also gives a negative impact on human health as if the hearing loss, hypertension, ischemic heart disease, annoyance, and sleep disturbance. Hereupon noise is dangerous to the environment as well as human being health so the noise control or noise mitigation is required to reduce the negative impact of noise pollution on the environment and human being. Noise control or mitigation is a technique of reducing unwanted sound emissions. There are various techniques of noise control or mitigation as if sounds insulation, sound absorption, vibration damping, and vibration isolation. This paper only highlights the noise mapping using GIS.

After critically studying literature review on traffic noise mapping the gap in research in urban Indian context comes out as below:

The appropriate tool is not used for application for environmental noise planning of roads in Indian urban context. Still, research is not yet reported by integrating the noise prediction model and GIS together in Indian urban city. Also, such 3-D noise maps, in Indian conditions have not been developed.
A GIS-based noise mapping is beneficial for the better conception of noise pollution in the map form. A well understanding of noise disparity in the study area can efficiently assist to urban and transportation planner for the planning and design of green belts, noise barriers which will ultimately reduce the noise levels by the substantial amount.

\section{References}

1. Silvia R, Hernandez R, Cueto JL. Evaluation and prediction of noise pollution levels in urban areas of Cdiz (Spain). The Journal of the Acoustical Society of America. 2003; 114:2439. https://doi.org/10.1121/1.4779173

2. Canter L. Environmental impact assessment. Mc-GrawHill, New York; 1996. p. 304-40.

3. Planning the acoustic urban environment; A GIS Centred Approach [Internet]. [cited 1999]. Available from: http:// citeseerx.ist.psu.edu/viewdoc/download?doi=10.1.1.17.211 \&rep $=$ rep $1 \&$ type $=$ pdf.

4. Abbaspour M, Golmohammadi R, Nassiri P, Mahjub H. an investigation on time-interval optimization of traffic noise measurement. Journal of Low Frequency Noise Vibration and Active Control. 2006; 25(4):267-73. https:// doi.org/10.1260/026309206779884883

5. Wazir A. GIS based Assessment of noise pollution in Guwahati City of Assam. International Journal of Environmental Sciences. 2011; 2(2):743-51.

6. Sukru D, Celalettin O. Noise pollution and map of Konya city in Turkey. Journal of International Environmental Application and Science. 2006; 1(1-2):63-72.

7. Davis E, Bruce E. GIS: A visual approach. Cengage Learning; 2001. p. 1-438.

8. Buckley DJ. The GIS primer: An introduction to Geographical information systems. Forests and Forestry; 1990. p. 1-184.

9. Knight R. A strategic approach with Modern Physics (3rd Edition). Physics for Scientists and Engineers; 2008. p. 620-9.

10. The harmonoise noise prediction algorithm: Validation and use under Australian Conditions [Internet]. [cited 2012 Nov 23]. Available from: https://www.acoustics.asn.au/conference_proceedings/AAS2012/papers/p43.pdf.

11. Nord2000: Nordic Noise Prediction methods.

12. Yilmaz G, Hocanli Y. Mapping of noise by Using GIS in Sanliurfa. Environmental Monitoring and Assessment. 2006; 121(1-3):103-8. https://doi.org/10.1007/s10661-0059109-1. PMid:16741792

13. Fink A. Conducting research literature reviews: From the Internet to Paper. SAGE; 2005. p. 1-245. 
14. Booth A, Papaioannou D, Sutton A. Systematic approaches to a successful literature review. SAGE Publications Ltd.; 2012. p. 1-288. PMCid:PMC3515971

15. Jesson J, Matheson L, Lacey F. Doing your literature review traditional and systematic techniques. SAGE Publications Ltd.; 2011. p. 1-192.

16. Majeed Z, Parker D. Geographic Information System (GIS) for managing survey data to the development of GIS-ready information. 3rd FIG Regional Conference; 2004. p. 1-14.

17. Stimac A. The application of the noise mapping technique in the complex industrial environment. 2nd Congress of Alps-Adria Acoustics Association and 1st Congress of Acoustics Society of Crotia; 2005. p. 195-202.

18. Environmental noise prediction, noise mapping and GIS integration: the case of inner Dublin, Ireland [Internet]. [cited 2006]. Available from: https://researchrepository. ucd.ie/handle/10197/3000.

19. Kurakula V. A GIS-based approach for 3D noise modeling using 3D City models. Master of Science (MSc) thesis, the International Institute for Geo-information Science and Earth; 2007. p. 1-129.

20. Urban Noise Mapping: The Case of the City of El-Mina, North Lebanon [Internet]. [cited 2007]. Available from: https://pdfs.semanticscholar.org/a116/6beb939441a8b713 1f4701544e8f7a8ef886.pdf.

21. Community and Regional Noise Mapping in the United States [Internet]. [cited 2007]. Available from: http://www. sandv.com/downloads/0709kali.pdf.

22. Noise Map from two computer programs. analysis of differences [Internet]. [cited 2008 Oct 22]. Available from: http:// www.sea-acustica.es/fileadmin/publicaciones/Coimbra08_ id171.pdf.

23. Golmohammadi R, Abbaspour M, Nassiri P, Mahjub H. A compact model for predicting road traffic noise. Journal of Environmental Health Science and Engineering. 2009; 6(3):181-6.

24. Banerjee D, Chakraborty S, Bhattacharyya S, Gangopadhyay A. Appraisal and mapping the spatial-temporal distribution of urban road traffic noise. International Journal of Environmental Science and Technology. 2009; 6(2):325-35. https://doi.org/10.1007/BF03327636
25. Alesheikh A, Omidvari M. Application of GIS in urban traffic noise pollution. International Journal of Occupational hygiene; 2010. p. 79-84.

26. Tandel B, Macwan J, Ruparel P. Urban corridor noise pollution: A case study of Surat city, India. International Conference on Environment and Industrial Innovation. 2011; 12:144-8.

27. Hunashala R, Patil Y. Assessment of noise pollution indices in the city of Kolhapur. International Conference on Emerging Economies -Prospects and Challenges, Procedia - Social and Behavioral Science; 2012. p. 448-57. https:// doi.org/10.1016/j.sbspro.2012.03.310

28. Akhtar N, Ahmad K, Gangopadhyay S. Road traffic noise mapping and a case study for Delhi region. International Journal of Applied Engineering and Technology. 2012; 2(4):39-45.

29. Production of Geographic Information System Aided Noise Maps [Internet]. [cited 2012]. Available from: http://www. fig.net/resources/proceedings/fig_proceedings/fig2012/ papers/ts07d/TS07D_geymen_bostanci_6116.pdf.

30. Maciej S, Kotus J, Andrzej C, Bozena K. The application of noise mapping tool deployed in grid infrastructure for creating noise maps of urban areas. Journal of computer science. 2013; 16(4):313-20.

31. Karthik K, Partheeban P. Study of traffic noise pollution on busy corridors in Chennai. Journal of Law, Science and Technology. 2013; 3(1):123-7.

32. Bayan M, Rana I, Ahmad J. Noise mapping using GIS: A case study from Amman. Journal of American Science. 2013; 9(12):646-52.

33. Keerthana R, Singhvi N, Chitravel V, Sarany S, Kannan T. An analysis of noise pollution in Tirupur city. Scholars Journal of Engineering and Technology. 2013; 1(3):154-68.

34. Ming Cai, Jingfang Z, Jiemin X, Xialin M. Road traffic noise mapping in Guangzhou using GIS and GPS. Applied Acoustics 87, China; 2015. 94-102.

35. Tahlyan D, Ohri A. GIS-based simplistic noise prediction model for urban areas. International Journal of Civil, Structural, Environmental and Infrastructure Engineering Research and Development. 2015; 5(1):75-82. 